Хомік M. М., канд. техн. наук, ст. наук. співроб. (ORCID 0000-0002-1201-7702)

Центр воєнно-стратегічних досліджень Національного університету оборони України імені Івана Черняховського, Київ

\title{
Проблемні аспекти управління екологічною безпекою при застосуванні Збройних Сил України під час надзвичайних ситуацій і в районі проведення операції Об'сднаних Сил
}

Резюме. Розглядаються проблемні питання управління екологічною (техногенною) безпекою за умови врахування ризику задіяного особового складу при застосуванні Збройних Сил України та інших військових формувань під час надзвичайних ситуацій, зокрема в районі проведення Операції Об'єднаних Сил. Результати дослідження можуть бути використані у процесі розроблення нових або трансформації до сучасних умов існуючих підходів, принципів, концепцій, стратегій, форм, методів управління екологічною (техногенною) безпекою.

Ключові слова: екологічна безпека; техногенна безпека; ліквідація наслідків; надзвичайні ситуації; застосування військ (сил); ризик.

Постановка проблеми. Територія України є об’єктом виникнення надзвичайних ситуацій природного i техногенного характеру. Це обумовлено наявністю великої кількості потенційно небезпечних об'єктів та щільності їх розташування, а саме:

п'яти атомних електростанцій 3 п'ятнадцятьма реакторами, двох дослідних реакторів, загальна площа зон радіаційного зараження під час надзвичайної ситуації на одному 3 реакторів складе 331 тис. км ${ }^{2}$ (приблизно 50 \% території держави);

1789 хімічних підприємств 3 небезпечними хімічними речовинами (НХР) із загальною площею можливого зараження 81 тис. км ${ }^{2}$ (понад $13 \%$ території держави);

12 гідровузлів та 16 водосховищ загальною площею можливого затоплення більше 6,3 тис. км ${ }^{2}$ (близько $2,4 \%$ території держави);

7 біологічно-небезпечних підприємств та 149 біологічно-небезпечних осередків захоронення загальною площею небезпечних зон за епідемічними та епізоотичними показниками 146 тис. км ${ }^{2}$ (понад $22 \%$ території держави) [1-5].

Крім того, під час ведення антитерористичної операції та Операції Об'єднаних сил на сході нашої держави, можуть утворюватися надзвичайні ситуації воєнного характеру, до того ж наслідки таких надзвичайних ситуацій подеколи можуть перевищувати наслідки надзвичайних ситуацій техногенного характеру i використовуватися для досягнення військових цілей.

Зрозуміло, що за таких умов важливим постає завдання щодо здійснення цілеспрямованого впливу на стан захищеності населення, території, об'єктів від негативних наслідків надзвичайних ситуацій різного характеру для підвищення іiі рівня, тобто управління екологічною безпекою $\mathrm{i}$ iii складовою - техногенною безпекою.

Проте таке управління буде ефективним лише у разі знайдення шляхів підвищення рівня екологічної (техногенної) безпеки, що неможливо без виявлення проблемних питань.

Поряд із відомими формами і методами управління екологічною (техногенною) безпекою, пропонується здійснювати цілеспрямований вплив через врахування ризику задіяного особового складу під час застосування Збройних Сил України та інших військових формувань при ліквідації наслідків надзвичайних ситуацій різного характеру.

Наведене підтверджує актуальність та перспективність досліджень цієї проблематики.

Аналіз останніх досліджень i публікацій. У провідних країнах світу відбуваються докорінні зміни в характері ліквідації наслідків надзвичайних ситуацій. Від масштабних дій (організація ліквідації наслідків надзвичайних ситуацій на Чорнобильській AEC, яка здійснювалася із залученням значної кількості сил), ці країни переходять до конкретних, цілеспрямованих й обгрунтованих дій мінімально необхідним складом сил і $з$ мінімальним ризиком для нього [1, 6-8].

До того ж аналіз організації ліквідації наслідків надзвичайних ситуацій природного i техногенного характеру свідчить про стійку тенденцію залучення до цього процесу військ (сил) національних збройних сил. Тільки за останні десятиріччя відомо приблизно 
300 випадків застосування військ (сил) під час ліквідації наслідків надзвичайних ситуацій природного і техногенного характеру [6-8].

Нині в Україні розроблені певні нормативно-правові акти, які регламентують цивільний захист $[9,10]$, проте, водночас відсутні загальнодержавні Концепція i Стратегія управління екологічною (техногенною) безпекою, які визначали б єдині підходи до зменшення техногенних ризиків, не затверджені норми прийнятного техногенного ризику для населення та задіяного у ліквідації наслідків надзвичайних ситуацій особового складу. Крім того, у державних нормативно-правових актах нині відсутні відповідні положення, які б забезпечили обов'язкове упровадження в усіх галузях економіки сучасної низової ланки функціональних систем управління техногенною безпекою ризик-орієнтованого підходу.

Хоча, на сьогодні постійно зростає фінансування наукових досліджень в області організації та здійснення ліквідації наслідків надзвичайних ситуацій $\mathrm{i}$ досить велике коло зарубіжних і вітчизняних вчених у своїх роботах торкається зазначених питань $[1-8$, 11], в Україні практично відсутні наукові дослідження присвячені пошуку нових, або трансформації до сучасних умов існуючих підходів щодо забезпечення необхідного рівня екологічної (техногенної) безпеки за умови врахування ризику задіяного особового складу під час застосування Збройних Сил України та інших військових формувань під час ліквідації наслідків надзвичайних ситуацій різного характеру.

Метою статті $\mathbf{\epsilon}$ пошук проблемних питань управління техногенною безпекою за умови врахування ризику задіяного особового складу під час застосування Збройних Сил України та інших військових формувань під час ліквідації наслідків надзвичайних ситуацій природного, техногенного i воєнного характеру.

Виклад основного матеріалу. Проведений аналіз законодавства України, керівних документів Міністерства оборони України, Міністерства внутрішніх справ України, Державної служби України 3 надзвичайних Ситуацій, наявних теоретичних підходів щодо застосування Збройних Сил України та інших військових формувань під час надзвичайних ситуацій природного, техногенного і воєнного характеру, зокрема під час ліквідації їх наслідків, свідчить про відсутність загального розуміння такого складного завдання.

Крім того, в практиці виникає суперечлива ситуація між наявністю високого ризику задіяного під час ліквідації наслідків надзвичайних ситуацій особового складу та відсутністю механізму врахування цього ризику під час застосування Збройних Сил України та інших військових формувань.

Звичайно, що проблемних питань такого застосування існує досить велика кількість, починаючи від нормативно-правового врегулювання цієї діяльності та закінчуючи міжвідомчою підготовкою фахівців, доцільно зосередитися на нормативно-правових, організаційних аспектах i проблемах забезпечення.

Основною нормативно-правовою проблемою застосування Збройних Сил України та інших військових формувань під час надзвичайних ситуацій природного, техногенного і воєнного характеру є той факт, що не створена єдина система 3 протидії надзвичайним ситуаціям.

Відповідно до чинного законодавства України у сфері цивільного захисту $[9,10]$ функціонує єдина державна система цивільного захисту, на яку покладені певні завдання:

забезпечення готовності міністерств та інших центральних i місцевих органів виконавчої влади, органів місцевого самоврядування, підпорядкованих їм сил i засобів до дій, спрямованих на запобігання i реагування на надзвичайні ситуації;

забезпечення реалізації заходів щодо запобігання виникненню надзвичайних ситуацій;

навчання населення щодо поведінки та дій у разі виникнення надзвичайної ситуації; виконання державних цільових програм, спрямованих на запобігання надзвичайним ситуаціям, забезпечення сталого функціонування підприємств, установ та організацій, зменшення можливих матеріальних втрат;

опрацювання інформації про надзвичайні ситуації, видання інформаційних матеріалів 3 питань захисту населення i територій від наслідків надзвичайних ситуацій;

прогнозування і оцінювання соціальноекономічних наслідків надзвичайних ситуацій, визначення на основі прогнозу потреби в силах, засобах, матеріальних і фінансових ресурсах;

створення, раціональне збереження i використання резерву матеріальних i фінансових ресурсів, необхідних для запобігання i реагування на надзвичайні ситуації; 
оповіщення населення про загрозу та виникнення надзвичайних ситуацій, своєчасне та достовірне інформування про фактичну обстановку і вжиті заходи;

захист населення у разі виникнення надзвичайних ситуацій;

проведення рятувальних та інших невідкладних робіт щодо ліквідації наслідків надзвичайних ситуацій, організація життєзабезпечення постраждалого населення; пом'якшення можливих наслідків надзвичайних ситуацій у разі їх виникнення; здійснення заходів щодо соціального захисту постраждалого населення; реалізація визначених законом прав у сфері захисту населення від наслідків надзвичайних ситуацій, зокрема осіб (чи їx сімей), що брали безпосередню участь у ліквідації цих ситуацій;

інші завдання.

Між іншим:

структура єдиної державної системи цивільного захисту неупорядкована, оскільки детально регламентовано застосування лише сил та формувань цивільного захисту;

управління процесами цивільного захисту потребує оптимізації, зокрема 3 урахуванням застосування Збройних Сил України та інших військових формувань;

територіальні функціональні підсистеми єдиної державної системи цивільного захисту в більшості не сформовані, а функціональні підсистеми зазначеної системи не готові до виконання покладених завдань в умовах проведення операції Об'єднаних сил;

на регіональному рівні існує дублювання управлінських функцій;

у більшості центральних органів виконавчої влади скорочені підрозділи, які займаються організацією та здійсненням цивільного захисту;

у законодавстві у сфері цивільного захисту мають місце певні суперечності та протиріччя нормативного, правового, організаційного характеру, через це виникають непорозуміння в організації управління, функціонуванні єдиної державної системи цивільного захисту, і як результат зниження ефективності виконання завдань загалом.

Крім того, законодавство України у сфері цивільного захисту вступає в певні протиріччя із законодавством України у сфері оборони України [12-16] в аспекті застосування Збройних Сил України та інших військових формувань під час надзвичайних ситуацій, особливо воєнного характеру. Так, наприклад, під час виконання завдань територіальної оборони Збройні Сили України здійснюватимуть: проведення аварійнорятувальних та інших невідкладних робіт у небезпечних районах; захист населення від наслідків воєнних дій, аварій (руйнувань), зумовлених застосуванням засобів ураження, терористичними актами та диверсіями (фактично заходи цивільного захисту). До того ж у Законі України "Про оборону України" та у "Положенні про територіальну оборону України” визначено, що територіальну оборону на всій території України організовує Генеральний штаб Збройних Сил України. Водночас, відповідно до Кодексу цивільного захисту України - організація здійснення заходів цивільного захисту, зокрема щодо ліквідації наслідків надзвичайних ситуацій, $€$ повноваженням Кабінету Міністрів України.

Крім того, чинним законодавством не передбачене відповідне забезпечення Збройний Сил України при виконання ними окремого завдання щодо ліквідації наслідків надзвичайних ситуацій та нормативно не визначено рівень допустимого ризику для задіяного особового складу Збройний Сил України та інших військових формувань під час виконання цього завдання.

Поряд із невідповідностями законодавчого характеру присутні невідповідності організаційного характеру, які пов'язані 3 функціонуванням певних суб'єктів цивільного захисту - Державної служби України 3 надзвичайних ситуацій, Збройних Сил України та інших військових формувань, а саме:

відсутність в Збройних Силах України та інших військових формуваннях (крім Державної служби України 3 надзвичайних ситуацій) відповідної до завдань ліквідації наслідків надзвичайних ситуацій організаційноштатної структури;

відсутність міжвідомчої підготовки особового складу до дій в умовах надзвичайних ситуацій та ліквідації їх наслідків;

відсутність у Державній служби України 3 надзвичайних ситуацій можливості відмобілізовувати сили на укомплектування та доукомплектування своїх сил;

відсутність у Збройних Силах України та інших військових формуваннях мобілізаційних резервів на укомплектування сил на період організації ліквідації наслідків надзвичайних ситуацій;

відсутність в Збройних Силах України та інших військових формуваннях статутних документів, які регламентують залучення сил i 
засобів військ (сил) під час ліквідації наслідків надзвичайних ситуацій;

низькі можливості сил Державної служби України 3 надзвичайних ситуацій щодо ліквідації

масштабних надзвичайних ситуацій та їх наслідків;

відсутність оперативної підготовки (в аспекті організації ліквідації наслідків надзвичайних ситуацій) органів військового управління Збройних Сил України;

відсутність можливості врахування ризику задіяного особового складу під час організації спеціальних робіт.

Імовірно за все, здебільшого, проблеми застосування Збройних Сил України та інших військових формувань під час надзвичайних ситуацій нормативно-правового та організаційного характеру породжують проблеми забезпечення такого застосування, особливо забезпечення.

Однією з таких проблем є відсутність у Державній службі України 3 надзвичайних ситуацій сил, що призначені для польового матеріально-технічного забезпечення. Під час виконання аварійно-рятувальних та інших невідкладних робіт зазначені сили спираються на місцеву базу господарства України, у тому числі на місцеві людські ресурси $[9,10]$. Під час масштабних надзвичайних ситуацій, коли передбачається евакуація населення i матеріальних засобів з небезпечних територій, матеріально-технічне забезпечення заходів 3 ліквідації наслідків надзвичайних ситуацій за допомогою місцевих ресурсів стає проблематичним або унеможливлюється.

Зазначене створює проблемну ситуацію, яка полягає у відсутності в Державній службі України з надзвичайних ситуацій оперативних можливостей забезпечити ведення тривалих спеціальних робіт в умовах надзвичайних ситуацій.

Крім того, існує низка інших проблемних аспектів забезпечення заходів ліквідації наслідків надзвичайних ситуацій, а саме:

озброєння і військова техніка Збройних Сил України не відповідає вимогам заходів ліквідації наслідків надзвичайних ситуацій;

засоби захисту, що перебувають на озброєнні військ (сил) неспроможні ефективно захищати від небезпечних хімічних та радіоактивних речовин;

відсутність запасів дегазаторів, дезактиваторів, дезінфекторів тощо; відсутність засобів індикації небезпечних хімічних речовин;

відсутність сумісності засобів зв'язку органів управління Збройних Сил України, інших військових формувань та Державної служби України з надзвичайних ситуацій;

наявність різного озброєння і спеціальної техніки (як правило, не сумісних) у Збройних Силах України, інших військових формуваннях та Державній службі України з надзвичайних ситуацій;

низький рівень підготовки особового складу Збройних Силах України та інших військових формувань діяти в умовах надзвичайних ситуацій спеціальним та нештатним озброєнням і технікою.

\section{Висновки}

1. На основі аналізу нормативно-правових актів, інших документів, які регламентують організацію та здійснення цивільного захисту; досвіду ліквідації наслідків надзвичайних ситуацій природного, техногенного і воєнного характеру у світі й в Україні та застосування національних збройних сил, інших військових формувань під час таких ситуацій було виявлено низку проблемних питань нормативного, організаційного характеру та проблем забезпечення.

2. Безперечно, розв'язання зазначених проблем дасть змогу не тільки підвищити ефективність цивільного захисту, а й управління техногенною безпекою за умови врахування ризику задіяного особового складу під час застосування Збройних Сил України та інших військових формувань під час ліквідації наслідків надзвичайних ситуацій природного, техногенного і воєнного характеру, зокрема в районі проведення Операції Об'єднаних Сил.

\section{СПИСОК ВИКОРИСТАНОЇ ЛІТЕРАТУРИ}

$\begin{array}{ccc}\text { 1. Биченок М. М. Ризики } & \text { життєдіяльності } \\ \text { природно-техногенному } & \text { середовищі }\end{array}$ М. М Биченок, С. П. Іванюта, Є. О. Яковлев // Інститут проблем безпеки РНБО. - К.: 2008. $160 \mathrm{c}$.

2. Іванюта С. П. Екологічна та природно-техногенна безпека України: регіональний вимір загроз $\mathrm{i}$ ризиків / С. П. Іванюта, А. Б. Качинський // Національний інститут стратегічних досліджень. К.: 2012. $-308 \mathrm{c}$.

3. Мун Д. В. От “Титаника" до "Фукусимы”: алгоритмы техногенных катастроф / Д.В. Мун, В. В. Попета, П. Е. Смолков // Профессиональное сообщество "Объединение инженеров". - М.: ООО “Рива Стар", 2018. - 394 с.

4. Хомік М. М. Оцінка та управління ризиками застосування збройних Сил України під час ліквідації наслідків надзвичайних ситуацій / 
Хомік М. М., Барабаш О. В. // Полтавський національний технічний університет імені Юрія Кондратюка. Системи управління, навігації та зв'язку: Запобігання та ліквідація надзвичайних ситуацій. Полтава: ПНТУ, 2016. - № 4 (40). C. 133-138.

5. Хомік М. М. Закономірності застосування військ (сил) Збройних Сил України та інших військових формувань під час ліквідації наслідків надзвичайних ситуацій / М. М. Хомік // Техногенно-екологічна безпека та цивільний захист. К.: ДУ ІГНС НАНУ, 2017. - Вип. 2 (6). C. 67-75.

6. Опастности техногенного характера и защита от них: Учебное пособие. - М.: Издательство СКФУ. - 2016. - 141 с.

7. Хомік М. М. Оперативно-стратегічна оцінка наслідків надзвичайних ситуацій на території України / М. М. Хомік, Н. В. Вавілова // Техногенно-екологічна безпека та цивільний захист. Вип. 4 (10). - Київ: ДУ ІГНС НАНУ, 2017. - C. 69-78.

8. Хомік М. М. Концептуальні основи застосування Збройних Сил та інших військових формувань під час ліквідації наслідків надзвичайних ситуацій 3 врахуванням ризику професійної діяльності задіяного особового складу 3 метою управління техногенною безпекою / М. М. Хомік // Journal of Scientific Papers "Social Development and Security", volume 9, issue 3, june 2019. P. 91105.

9. Кодекс цивільного захисту України: Офіційний текст зі змінами станом на 2 жовтня 2018 /
Відомості Верховної ради України (ВВР), 2018, № 46, ст. 371 .

10. Положення про єдину державну систему цивільного захисту: Офіційний текст зі змінами станом на 6 червня 2018 / Постанова КМ України від 6.06.2018 № 450.

11. Хомік М. М. Аналітично-імітаційна модель (структурний аспект) застосування військ (сил) Збройних Сил України та інших військових формувань під час ліквідації наслідків надзвичайних ситуацій / М. М. Хомік // науковотехнічний журнал "Наука i техніка Повітряних Сил Збройних Сил України”. № 2 (35). - Харків: ХНУПС ім. Івана Кожедуба, 2019. - С. 176-183.

12. Закон України "Про оборону України": Офіційний текст зі змінами станом на 6 червня 2019.

13. Закон України “Про збройні Сили України”: Офіційний текст зі змінами станом на 2 жовтня 2018 / Відомості Верховної ради України (ВВР), 2018, № 46, ст. 371 .

14. Закон України "Про правовий режим воєнного стану”: Офіційний текст зі змінами станом на 5 квітня 2018.

15. Закон України "Про правовий режим надзвичайного стану”: Офіційний текст зі змінами станом на 23 грудня 2015 / Відомості Верховної ради України (ВВР), 2016, № 4, ст. 44.

16. Положення про територіальну оборону України: Указ Президента України від 23 вересня 2016 року № 406/2016.

Стаття надійшла до редакційної колегії 11.07.2019

Хомик Н. Н., канд. техн. наук, ст. науч. сотрудник

Центр военно-стратегических исследований Национального университета обороны Украины имени Ивана Черняховського, Киев

Проблемные аспекты управления экологической безопасностью при применении Вооруженных Сил Украины во время чрезвычайных ситуаций и в районе проведения операции Объединённых Сил

Резюме. Рассматриваются проблемные вопросы управления техногенной безопасностью за счет учёта риска задействованного личного состава при применении Вооруженных Сил Украины и других военизированных формирований во время чрезвычайных ситуаций, в том числе в районе проведения операции Объединённых Сил. Результаты исследования могут быть использованы при разработке новых или трансформации с учётом современных условий, существующих подходов, принципов, концепций, стратегий, форм, методов управления экологической (техногенной) безопасностью.

Ключевые слова: экологическая безопасность; техногенная безопасность; ликвидации последствий; чрезвычайные ситуации; применение войск (сил); риск.

\section{N. Chomik, PhD (Technical), senior researcher}

Centre for Military and Strategic Studies National Defence University of Ukraine named after Ivan Cherniakhovskyi, Kyiv

Problematic aspects of environmental safety management in the use of the Armed Forces of Ukraine during emergencies and in the area of operation of the United Forces

Resume. The problematic issues of man-made safety management are considered by taking into account the risk of personnel involved in the use of the Armed Forces of Ukraine and other paramilitary forces during emergencies, including in the area of the operation of the United Forces. The results of the study can be used in: developing new ones or transforming taking into account modern conditions, existing approaches, principles, concepts, strategies, forms, methods of managing environmental (ethnogeny) safety.

Keywords: environmental safety; technological safety; liquidation of consequences; emergency situations; use of troops (forces); risk. 